\title{
OPEN Curcubinoyl flavonoids from wild ginseng adventitious root cultures
}

\author{
Qing Liu ${ }^{1}$, Seon Beom Kim ${ }^{1}$, Yang Hee Jo ${ }^{1}$, Jong Hoon Ahn ${ }^{1}$, Ayman Turk ${ }^{1}$, Da Eun Kim², \\ Bo Yoon Chang ${ }^{2}$, Sung Yeon Kim ${ }^{2}$, Cheol-Seung Jeong ${ }^{3}$, Bang Yeon Hwang ${ }^{1}$, \\ So-Young Park ${ }^{3 \bowtie}$ \& Mi Kyeong Lee ${ }^{1 \bowtie}$
}

Wild ginseng (Panax ginseng) adventitious root cultures were prepared by elicitation using methyl jasmonate and investigated further to find new secondary metabolites. Chromatographic fractionation of wild ginseng adventitious root cultures led to the isolation of eleven compounds. The chemical structures of isolated compounds were identified as four known flavanone derivatives (1-4), one new curcubinoyl derivative, jasmogin A (5) and six new curcubinoyl-flavanone conjugates, jasmoflagins A-F (6-11) by extensive spectroscopic analysis. Newly isolated curcubinoyl derivatives showed inhibitory activity against lipopolysaccharide-stimulated nitric oxide production in RAW 264.7 macrophages. Therefore, our present study suggested that elicitor stimulated plant cell cultures might contribute to the production of new metabolites.

Natural products contain a variety of ingredients and have long been used to prevent and treat diseases. However, securing natural products is essential in order to develop these natural products, which is sometimes not easy due to various constraints. Plant tissue culture technology is suggested as a powerful tool for obtaining natural substances ${ }^{1-3}$. This is widely used for the production of plant materials because it is less affected by weather and other external conditions than plant cultivation and relatively for a short period of time.

For maximum productivity, culture conditions such as culture medium and the incubation conditions, etc., are optimized when growing plant tissues ${ }^{4-6}$. In particular, the use of elicitors is widely used for increased productivity and useful substances. As elicitors, salicylic acid and methyl jasmonate (MJ), which control the immune of plants, are most widely used ${ }^{7-8}$. These elicitors greatly increase the content of biomass and useful metabolites ${ }^{4,9}$. Moreover, new ingredients have been reported in elicitor-stimulated plant cell culture ${ }^{10-11}$. Therefore, plant tissue culture has become an important tool not only for securing plant materials but also finding new metabolites.

Panax ginseng C.A. Meyer (Araliaceae) is commonly known as Korean ginseng. It is one of the most widely used tonic to enhance immune response and consequent health and longevity for over 2000 years in Oriental countries $^{12}$. Various efficacy of $P$. ginseng, including anti-cancer, anti-inflammatory, anti-diabetic, anti-fatigue and neuroprotective activities have been also reported from a lot of research ${ }^{13-16}$.

Ginseng grows in wild environment or is cultivated on farm. Cultivated ginseng is systematically grown on farm under the control of growth condition and harvested after 4-6 year cultivation. The wild ginseng, also called mountain ginseng in Korea, grows without human touch in deep areas with low sunlight and temperature changes. This difference in the cultivation environment and genotypes leads to differences in the composition and efficacy of the two specimens. Wild ginseng has been reported to have enhanced host defense components and biological activities. The concentration of ginsenosides and amino acids in wild ginseng were much higher than those of cultivated ginseng ${ }^{17,18}$.

However, due to the short supply and consequent high price of wild ginseng has limited its usage despite of beneficial biological activities. Therefore, sufficient production is required for the development as products. As a preparation of wild ginseng, tissue culture system is considered as a valuable tool to achieve rapid and stable production of excellent individual. We previously established efficient adventitious root cultures of wild ginseng with fast growth and stable production ${ }^{19,20}$. In addition, we also demonstrated the increased yield and antioxidant activity of MJ-elicitated wild ginseng adventitious root cultures compared to MJ-untreated samples ${ }^{21}$. In the present study, MJ-treated wild ginseng adventitious root cultures were investigated further to find new secondary metabolites.

${ }^{1}$ College of Pharmacy, Chungbuk National University, Cheongju 28160, Republic of Korea. ${ }^{2}$ College of Pharmacy, Wonkwang University, Iksan 54538, Republic of Korea. ${ }^{3}$ Department of Horticultural Science, Chungbuk National University, Cheongju 28644, Republic of Korea. ${ }^{\circledR}$ email: soypark7@chungbuk.ac.kr; mklee@chungbuk.ac.kr 
<smiles>[R20]Oc1ccc([C@H]2CC(=O)c3c(O)cc(O[R2])cc3O2)cc1</smiles>

$1 \mathrm{R}_{1}=\mathrm{R}_{2}=\mathrm{H}$

$2 \mathrm{R}_{1}=\mathrm{Glu} \mathrm{R}_{2}=\mathrm{H}$

$3 \mathrm{R}_{1}=\mathrm{H} \mathrm{R}_{2}=\mathrm{Glu}$

$4 \mathrm{R}_{1}=\mathrm{CH}_{3} \mathrm{R}_{2}=\mathrm{Glu}$<smiles>[R6]C[C@H]1O[C@H](Oc2cc(O)c3c(c2)O[C@H](c2ccc(O)cc2)CC3=O)[C@H](O)[C@@H](O)[C@@H](O)[C@@H]1O</smiles><smiles>[R]CC(C)=O</smiles>

6<smiles>[Y]C(O)/C=C/C=C1[C@H](O)CC[C@@H]1CC(=O)O</smiles>

5

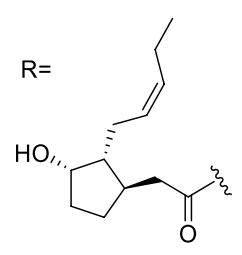

9<smiles>[Y]C(=O)C[C@H]1CC[C@H](O)[C@@H]1C/C=C\CCO</smiles>

7<smiles>[R][CH]C(=O)C[C@@H]1CC[C@H](O)[C@H]1CC(O)/C=C/C</smiles>

10<smiles>[Y]C(=O)C[C@H]1CCC(=O)[C@@H]1C/C=C\C(C)O</smiles><smiles>[R]C(=O)C[C@@H]1CC[C@@H](O)[C@H]1CC(O)C(N)CC</smiles>

11

Figure 1. Chemical structures of compounds from MJ-treated wild ginseng adventitious root cultures.

\section{Results and discussion}

Isolation of compounds from MJ-treated wild ginseng adventitious root cultures. Plant cell cultures were used not only for the stable production but also useful to find new secondary metabolites for better pharmacological activity ${ }^{9-11}$. Investigation on the constituents of the adventitious root cultures of $P$. ginseng yielded eleven compounds including seven new compounds (Fig. 1). Known compounds were identified as naringenin (1), naringenin-4'-O- $\beta$-glucoside (2), naringenin-7- $O$ - $\beta$-glucoside (3) and hesperetin 7 - $O$ - $\beta$-glucoside (4) by the analysis of their spectroscopic data and comparison with literature values ${ }^{22-24}$.

Structural determination of the new compounds. Compound $\mathbf{5}$ was obtained as a white amorphous powder. The molecular formula of 5 was determined as $\mathrm{C}_{12} \mathrm{H}_{20} \mathrm{O}_{4}$ by its HRESI-MS $\left(\mathrm{m} / z 251.1254[\mathrm{M}+\mathrm{Na}]^{+}\right.$, calcd. $\mathrm{C}_{12} \mathrm{H}_{20} \mathrm{NaO}_{4}$ 251.1253). In the ${ }^{1} \mathrm{H}$ and ${ }^{13} \mathrm{C}$ NMR spectrum, the presence of an olefinic moiety in cis-configuration was deduced from the signals at $\left[\delta_{\mathrm{H}} 5.52(1 \mathrm{H}, \mathrm{m}, \mathrm{H}-9), 5.42(1 \mathrm{H}, \mathrm{dd}, J=10.4,8.8 \mathrm{~Hz}, \mathrm{H}-10) ; \delta_{\mathrm{C}} 128.8\right.$ (C-9), 134.0 (C-10)]. The ${ }^{1} \mathrm{H}$ and ${ }^{13} \mathrm{C}$ NMR spectrum showed the signals attributed to two hydroxymethines at $\left[\delta_{\mathrm{H}} 4.15(1 \mathrm{H}, \mathrm{m}, \mathrm{H}-6), 4.68(1 \mathrm{H}, \mathrm{dq}, J=8.8,6.4 \mathrm{~Hz}, \mathrm{H}-11)\right]$, two methines at $\left[\delta_{\mathrm{H}} 2.16(1 \mathrm{H}, \mathrm{m}, \mathrm{H}-3), 1.46(1 \mathrm{H}, \mathrm{m}\right.$, $\mathrm{H}-7)]$ and one methyl group at $\left[\delta_{\mathrm{H}} 1.23(1 \mathrm{H}, \mathrm{d}, J=6.4 \mathrm{~Hz}, \mathrm{H}-12)\right.$. The ${ }^{1} \mathrm{H}$ NMR spectrum and the corresponding carbon signals in HSQC spectrum revealed the presence of four methylenes from the signals at $\left[\delta_{\mathrm{H}} 2.55(1 \mathrm{H}\right.$, dd, $\left.J=14.4,3.6 \mathrm{~Hz}, \mathrm{H}-2 \mathrm{a}), 2.15(1 \mathrm{H}, \mathrm{m}, \mathrm{H}-2 \mathrm{~b}) ; \delta_{\mathrm{C}} 39.1(\mathrm{C}-2)\right],\left[\delta_{\mathrm{H}} 1.88(1 \mathrm{H}, \mathrm{m}, \mathrm{H}-4 \mathrm{a}), 1.64(1 \mathrm{H}, \mathrm{m}, \mathrm{H}-4 \mathrm{~b}) ; \delta_{\mathrm{C}}\right.$ $32.8(\mathrm{C}-4)],\left[\delta_{\mathrm{H}} 2.11(1 \mathrm{H}, \mathrm{m}, \mathrm{H}-5 \mathrm{a}) ; 1.33(1 \mathrm{H}, \mathrm{m}, \mathrm{H}-5 \mathrm{~b}) ; \delta_{\mathrm{C}} 28.8(\mathrm{C}-5)\right]$ and $\left[\delta_{\mathrm{H}} 2.24(1 \mathrm{H}, \mathrm{m}, \mathrm{H}-8 \mathrm{a}), 2.29(1 \mathrm{H}, \mathrm{m}\right.$, $\left.\mathrm{H}-8 \mathrm{~b}) ; \delta_{\mathrm{C}} 25.5(\mathrm{C}-8)\right]$. In addition, a carbonyl signal was observed at $\delta_{\mathrm{C}} 175.9(\mathrm{C}-1)$ in the ${ }^{13} \mathrm{C}$ NMR spectrum. In the $\mathrm{HMBC}$ spectrum, correlations from $\mathrm{H}-4$ to $\mathrm{C}-6,7$ and from $\mathrm{H}-5$ to $\mathrm{C}-3$ suggested the presence of cyclopentyl moiety in $\mathbf{5}$. These NMR spectroscopic data of $\mathbf{5}$ were quite similar to those of curcurbic acid, a hydroxylated jasmonate derivative ${ }^{25}$, except for the additional hydroxyl group. The position of an additional hydroxyl group was determined to be C-11, which was confirmed by the HMBC correlations from H-11 to C-8, 12 (Fig. 2). The stereochemistry was determined by the NOESY correlations between H-6, H-7 and H-2 and between $\mathrm{H}-8$ and H-11 (Fig. 2). Taken together, compound 5 was defined as shown and named jasmogin A.

Compound 6 was purified as a white amorphous powder and assigned the molecular formula as $\mathrm{C}_{33} \mathrm{H}_{40} \mathrm{O}_{13}$ by its HRESI-MS $\left(m / z 667.2354[\mathrm{M}+\mathrm{Na}]^{+}\right.$, calcd. $\mathrm{C}_{33} \mathrm{H}_{40} \mathrm{NaO}_{13}$ 667.2331). The NMR spectroscopic clearly showed that $\mathbf{6}$ has hydroxylated curcurbic acid moiety of $\mathbf{5}$ as a partial structure. Additionally, compound $\mathbf{6}$ was supposed to be a glycoside from the anomeric signals at $\left[\delta_{\mathrm{H}} 4.96\left(1 \mathrm{H}, \mathrm{d}, J=7.4 \mathrm{~Hz}, \mathrm{H}-1^{\prime \prime}\right) ; \delta_{\mathrm{C}} 99.8\right]$ together with $\left[\delta_{\mathrm{H}}\right.$ 3.35-3.70 (4H, m, H-2", 3", 4", 5"), 4.43 (1H, dd, $J=11.7,2.1 \mathrm{~Hz}, \mathrm{H}-6$ "a), 4.21 (1H, m, H-6"b); $\delta_{\mathrm{C}} 76.4\left(\mathrm{C}-2^{\prime \prime}\right)$, $\left.73.2\left(\mathrm{C}-3^{\prime \prime}\right), 70.3\left(\mathrm{C}-4^{\prime \prime}\right), 74.2\left(\mathrm{C}-5^{\prime \prime}\right), 63.2\left(\mathrm{C}-6^{\prime \prime}\right)\right]$ in the ${ }^{1} \mathrm{H}$ and ${ }^{13} \mathrm{C}$ NMR spectrum. Besides aforementioned 
$[\mathrm{A}]$

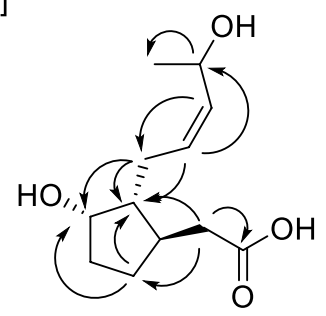

$[B]$

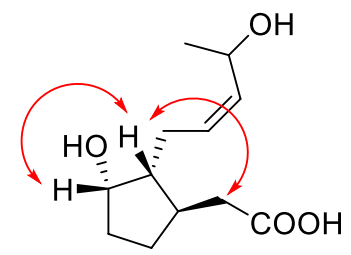

\section{5}

Figure 2. [A] Key HMBC $(\rightarrow)$ and $[\mathrm{B}]$ NOESY $(\leftrightarrow)$ correlations of compound 5 .

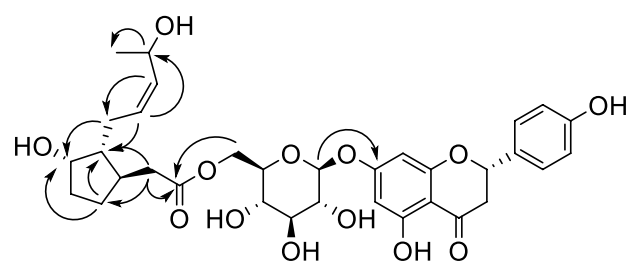

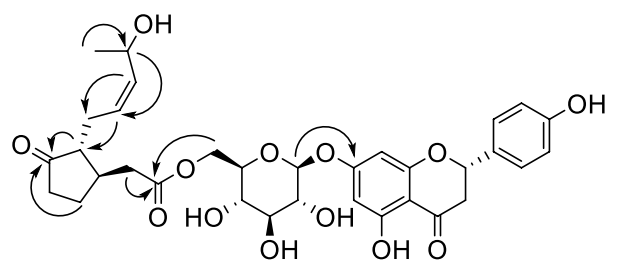

8

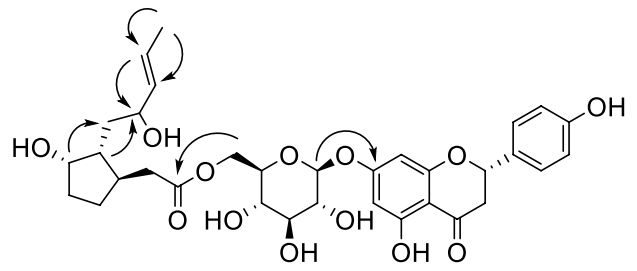

10

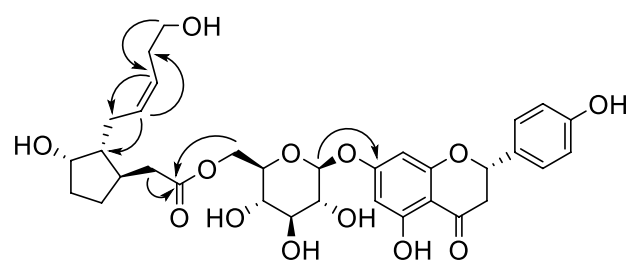

7

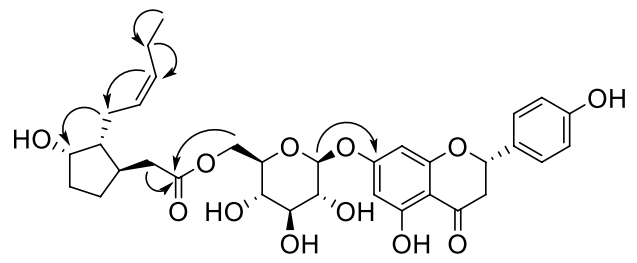

9

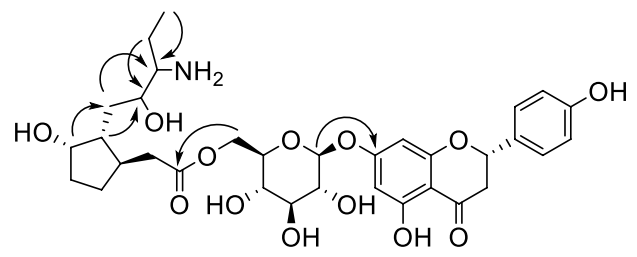

11

Figure 3. Key HMBC correlation of compounds 6-11.

moieties of curcurbic acid and glucose, the presence of disubstituted and tetrasubstituted aromatic rings were deduced from the signals at $\left[\delta_{\mathrm{H}} 7.34\left(2 \mathrm{H}, \mathrm{d}, J=8.0 \mathrm{~Hz}, \mathrm{H}-2^{\prime}, 6^{\prime}\right), 6.84\left(2 \mathrm{H}, \mathrm{d}, J=8.0 \mathrm{~Hz}, \mathrm{H}-3^{\prime}, 5^{\prime}\right) ; \delta_{\mathrm{C}} 129.5\left(\mathrm{C}-1^{\prime}\right)\right.$, $\left.128.9\left(\mathrm{C}-2^{\prime}, 6^{\prime}\right), 157.7\left(\mathrm{C}-4^{\prime}\right), 115.0\left(\mathrm{C}-3^{\prime}, 5^{\prime}\right)\right]$ and from the signals at $\left[\delta_{\mathrm{H}} 6.20(1 \mathrm{H}, \mathrm{d}, J=2.1 \mathrm{~Hz}, \mathrm{H}-6), 6.23(1 \mathrm{H}\right.$, d, $J=2.1 \mathrm{~Hz}, \mathrm{H}-8)$; $\delta_{\mathrm{C}} 163.2$ (C-5), 96.7 (C-6), 165.5 (C-7), 95.7 (C-8), 163.5 (C-9), 103.6 (C-10)], respectively, in the ${ }^{1} \mathrm{H}$ and ${ }^{13} \mathrm{C}$ NMR spectrum. From these two aromatic rings and together with additional signals at $\left[\delta_{\mathrm{H}} 5.40\right.$ $\left.(1 \mathrm{H}, \mathrm{dd}, J=13.0,3.0 \mathrm{~Hz}, \mathrm{H}-2), \delta_{\mathrm{C}} 79.3(\mathrm{C}-2)\right],\left[\delta_{\mathrm{H}} 3.17(1 \mathrm{H}, \mathrm{dd}, J=17.0,13.0 \mathrm{~Hz}, \mathrm{H}-3 \mathrm{a}), 2.77(1 \mathrm{H}, \mathrm{dd}, J=17.0,3.0\right.$, $\left.\mathrm{H}-3 \mathrm{~b}) ; \delta_{\mathrm{C}} 43.1(\mathrm{C}-3)\right]$ and carbonyl signal at $\delta_{\mathrm{C}} 197.2$ (C-4), compound 6 was supposed as a flavanone derivative, which was identified as naringenin $(\mathbf{1})^{23}$. Taken together, $\mathbf{6}$ was suggested as a flavanone glycoside consisting of naringenin, glucose and curcurbic acid moieties. The linkage of each unit was determined by cross peaks between $\mathrm{H}-1$ " of glucose and C-7 of naringenin, and between $\mathrm{H}-6$ " of glucose and C-1"' of curcurbic acid moiety in the HMBC spectrum (Fig. 3). Collectively, compound $\mathbf{6}$ was defined as shown and named jasmoflagin A.

Compound 7 was purified as a white amorphous powder and showed an HRESI-MS ion at $m / z 667.2354$ $\left([\mathrm{M}+\mathrm{Na}]^{+}\right.$, calcd 667.2361) for $\mathrm{C}_{33} \mathrm{H}_{40} \mathrm{NaO}_{13}$. The spectroscopic data of 7 were quite similar to those of 6 , which suggested that 7 is also a curcurbinoyl derivative of naringenin glycoside. Careful comparison of ${ }^{1} \mathrm{H}$ and ${ }^{13} \mathrm{C}$ NMR data of 7 with those of $\mathbf{6}$ showed the differences in the chemical shifts of $\mathrm{H}-11$ and H-12. The hydroxymethine 


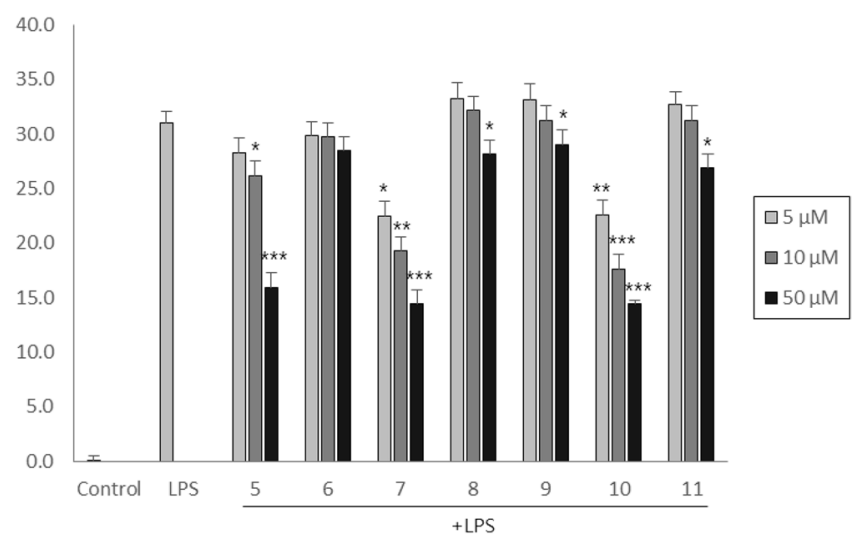

Figure 4. Inhibitory effects of compounds 5-11 on LPS-induced NO production in RAW 264.7 macrophage cells.

and methyl signals at $\delta_{\mathrm{H}} 4.62(\mathrm{H}-11)$ and $1.20\left(\mathrm{H}_{3}-12\right)$ in 6 were replaced by methylene at $\left[\delta_{\mathrm{H}} 2.37(1 \mathrm{H}, \mathrm{m}, \mathrm{H}-11 \mathrm{a})\right.$ and $\left.2.25(1 \mathrm{H}, \mathrm{m}, \mathrm{H}-11 \mathrm{~b}) ; \delta_{\mathrm{C}} 30.3\right]$ and hydroxymethylene at $\left.\delta_{\mathrm{H}} 3.56(2 \mathrm{H}, \mathrm{m}, \mathrm{H}-12) ; \delta_{\mathrm{C}} 61.2\right]$ in 7 . The correlation between $\mathrm{H}-10^{\prime \prime \prime}$ and $\mathrm{C}-11^{\prime \prime \prime}$ and between $\mathrm{H}-11^{\prime \prime \prime}$ and $\mathrm{C}-12^{\prime \prime \prime}$ confirmed the attachment of hydroxyl group to C-12 (Fig. 3). Taken together, compound 7 was determined as shown and named jasmoflagin B.

Compound $\mathbf{8}$ was also purified as a white amorphous powder. The molecular formula was established as $\mathrm{C}_{33} \mathrm{H}_{38} \mathrm{O}_{13}$ from an HRESI-MS ion at $\mathrm{m} / \mathrm{z} 665.2200\left([\mathrm{M}+\mathrm{Na}]^{+}\right.$, calcd 665.2204). The ${ }^{1} \mathrm{H}$ NMR spectrum of 8 were quite similar to those of 6 , except for the disappearance of hydroxymethine proton at $\delta_{\mathrm{H}} 4.05\left(\mathrm{H}-6^{\prime \prime \prime}\right)$ of 6. Additional carbonyl signal at $\delta_{\mathrm{C}} 220.1$ in the ${ }^{13} \mathrm{C}$ NMR spectrum suggested that 8 is a jasmonate derivative of naringenin glycoside. Further HMBC correlation from H-4"', H-5 $5^{\prime \prime \prime}, \mathrm{H}-7^{\prime \prime \prime}$ to C-6 $6^{\prime \prime \prime}$ confirmed the presence of carbonyl moiety at C-6"' (Fig. 3). Taken together, compound 8 was determined as shown and named jasmoflagin C.

Compound 9 was purified as a white amorphous powder and showed an HRESI-MS ion at $\mathrm{m} / \mathrm{z} 651.2404$ $\left([\mathrm{M}+\mathrm{Na}]^{+}\right.$, calcd 651.2412) for $\mathrm{C}_{33} \mathrm{H}_{40} \mathrm{NaO}_{12}$. The spectroscopic data of 9 suggested that 9 is also a curcurbinoyl derivative of naringenin glycoside. However, on the contrary to 6 and 7, hydroxymethine signals in curcurbic acid were not observed in the ${ }^{1} \mathrm{H}$ and ${ }^{13} \mathrm{C}$ NMR data of 9 . Further analysis demonstrated that the hydroxylmethine signals at $\left[\delta_{\mathrm{H}} 4.62(1 \mathrm{H}, \mathrm{m}, \mathrm{H}-11) ; \delta_{\mathrm{C}} 62.5\right]$ in 6 were replaced by methylene signals at $\left[\delta_{\mathrm{H}} 2.06(2 \mathrm{H}, \mathrm{m}, \mathrm{H}-11)\right.$; $\left.\delta_{\mathrm{C}} 20.1\right]$ in 9 . In addition, HMBC correlation between $\mathrm{H}-10^{\prime \prime \prime}$ and $\mathrm{C}-11^{\prime \prime \prime}$ and between $\mathrm{H}-11^{\prime \prime \prime}$ and C-12"' confirmed the detachment of hydroxyl group at C-11 in 6 (Fig. 3). Taken together, compound 9 was determined as shown and named jasmoflagin D.

Compound 10 was purified as white amorphous powder and assigned the molecular formula as $\mathrm{C}_{33} \mathrm{H}_{40} \mathrm{O}_{13}$, which is same as $\mathbf{6}$. The spectroscopic data of $\mathbf{1 0}$ were quite similar to those of $\mathbf{6}$ and suggested $\mathbf{1 0}$ is comprised of naringenin glucoside and curcurbic acid with a hydroxyl group. Differences in the ${ }^{1} \mathrm{H}$ and ${ }^{13} \mathrm{C}$ NMR data of $\mathbf{1 0}$ from those of $\mathbf{6}$ were observed as downfield shift of $\mathrm{CH}_{3}-12^{\prime \prime \prime}$ from $\delta_{\mathrm{H}} 1.20$ to $\delta_{\mathrm{H}} 1.68$ and upfield shift of $\mathrm{H}-8^{\prime \prime \prime}$ from $\delta_{\mathrm{H}} 2.04,2.31$ to $\delta_{\mathrm{H}} 1.60,1.70$, suggesting the change in the positions of hydroxyl group and double bond in curcurbic acid moiety. The ${ }^{1} \mathrm{H}-{ }^{1} \mathrm{H}$ COSY correlations of $\mathrm{H}-8^{\prime \prime \prime} / \mathrm{H}-9^{\prime \prime \prime}$ and $\mathrm{H}-11^{\prime \prime \prime} / \mathrm{H}-12^{\prime \prime \prime}$ together with $\mathrm{HMBC}$ correlations from H-12"' to C-11'" determined the position of hydroxyl group at C-9 $9^{\prime \prime \prime}$ (Fig. 3). Taken together, compound 10 was determined as shown and named jasmoflagin $\mathrm{E}$.

Compound 11 was obtained as white amorphous powder. The molecular formula of 12 was determined as $\mathrm{C}_{33} \mathrm{H}_{43} \mathrm{NO}_{13}$ by its HRESI-MS $\left(\mathrm{m} / z\right.$ 668.2415 $[\mathrm{M}+\mathrm{Li}]^{+}$, calcd. $\mathrm{C}_{33} \mathrm{H}_{43} \mathrm{NLiO}_{13}$ 668.2889). The ${ }^{1} \mathrm{H}$ and ${ }^{13} \mathrm{C} \mathrm{NMR}$ spectrum also proposed 11 as a curcubinoyl derivative of naringenin glucoside. The ${ }^{1} \mathrm{H}$ and ${ }^{13} \mathrm{C}$ NMR spectrum of 11 were comparable to those of 10, except for the disappearance of signals for double bond of curcurbic acid in 10. Additional methine signal at $\left[\delta_{\mathrm{H}} 3.24\left(1 \mathrm{H}, \mathrm{m}, \mathrm{H}-10^{\prime \prime \prime}\right) ; \delta_{\mathrm{C}} 74.5\right]$ and methylene signals at $\left[\delta_{\mathrm{H}} 1.40(2 \mathrm{H}\right.$, $\left.\mathrm{m}, \mathrm{H}-11^{\prime \prime \prime}\right) ; \delta_{\mathrm{C}} 26.2$ ] were observed in 11. These data suggested the presence of amine group to curcubinoyl moiety of 10, which is also confirmed by the presence of nitrogen in $\mathbf{1 1}$ from MS analysis. The positions of hydroxyl and amine groups were determined to be C- $9^{\prime \prime \prime}$ and C-10'", respectively, by the HMBC correlations from $\mathrm{H}-7^{\prime \prime \prime} / 8^{\prime \prime \prime}$ to $\mathrm{C}-9^{\prime \prime \prime}$ and from $\mathrm{H}-8^{\prime \prime \prime} / 12^{\prime \prime \prime}$ to $\mathrm{C}-10^{\prime \prime \prime}$ (Fig. 3). Taken together, compound 11 was defined as shown and named jasmoflagin $\mathrm{F}$.

NO inhibitory activity of isolated compounds. Next, we investigated the anti-inflammatory effects of newly isolated compounds by measuring the production of NO in LPS-stimulated RAW 264.7 macrophages. As shown in Fig. 4, compounds 5, 7 and $\mathbf{1 0}$ dose-dependently reduced NO production stimulated by LPS without any significant cytotoxic effects at the concentration ranging from 5 to $50 \mu \mathrm{M}$. Compound $\mathbf{5}$, which has only curcubinoyl moiety, inhibited NO production. However, addition of flavanone moiety to compound $\mathbf{5}$ reduced the inhibitory activity, as observed in compound 6. Interestingly, among the curcubinoyl flavanone derivatives, compounds $\mathbf{7}$ and $\mathbf{1 0}$ showed stronger inhibitory activity compared to others, which suggested the importance of the position of hydroxyl group in curcurbinoyl moiety. 


\section{Conclusion}

Fractionation of using various chromatographic techniques yielded eleven compounds from the MJ-treated adventitious root cultures of wild ginseng. The chemical structures of isolated compounds were identified by spectroscopic analysis and further identified seven new compounds. The newly reported compounds are curcubinoyl derivative, named jasmogin A (5) and curcubinoyl-conjugated flavanone derivatives, named jasmoflagins A-F (6-11). Considering the structural similarity between methyl jasmonate and curcubinoyl moiety, addition of elicitor can affect not only the increase of biosynthesis of active metabolite, but MJ itself also participate in biosynthetic pathway as a substrate, which needs to be clarified by further study.

\section{Materials and methods}

General experimental procedure. IR spectra were obtained using JASCO FTIR 4100 spectrometer in $\mathrm{CH}_{3} \mathrm{OH}$ solvent. Optical rotations were measured on a JASCO DIP-1000 polarimeter (Tokyo, Japan). HRESIMS data were measured on maXis 4G (Bruker) and LCQ Fleet (Thermoscientific), respectively. NMR spectra were recorded on a Bruker Avance 400, 500 and $800 \mathrm{MHz}$ spectrometers using $\mathrm{CD}_{3} \mathrm{OD}$ as solvent. Silica gel (200-400 mesh, Merck), Sephadex LH-20 (20-100 $\mu \mathrm{m}$, Sigma) and Diaion HP-20P (Mitsubishi Kasei, Japan) for column chromatography. TLC was performed on silica gel $60 \mathrm{~F}_{254}\left(0.2 \mathrm{~mm}\right.$, Merck) or silica gel $60 \mathrm{RP}-18 \mathrm{~F}_{254 \mathrm{~S}}(0.2 \mathrm{~mm}$, Merck), and spots were detected by a $10 \%$ vanillin- $\mathrm{H}_{2} \mathrm{SO}_{4}$ in EtOH spray reagent. MPLC was performed on a Biotage Isolera Prime chromatography system and a Lichroprep RP-18 column $(40-63 \mu \mathrm{m})$. Semi-prep HPLC was performed using a Waters system (three 515 pumps and a 996 photodiode array detector) with a Phenomenex Gemini-NX $5 \mu$ C18 110A column (USA). Details of NMR and HPLC methodology as well as NMR/NOESY spectra of new compounds are present in Supplementary Information.

Plant material. Wild ginseng was collected at Mt. Ohdae of Korea by the government certificated digger. It was identified by the Emeritus Prof. Kee-Yoeup Paek and certificated by Korea ginseng institutes. The permissions were obtained from concerned authorities for collection and use of sample. And all methods were performed in accordance with the relevant regulations.

Adventitious root cultures of wild ginseng ( $P$. ginseng) were produced from a 100-year-old wild ginseng through callus culture as we described previously ${ }^{20}$. The root cultures were proliferated in a $5 \mathrm{~L}$ airlift balloon type bioreactor containing 4.0 L Murashige and Skoog (MS) liquid medium (3/4 strength) supplemented with $5.0 \mathrm{mg} / \mathrm{L}$ IBA, $0.1 \mathrm{mg} / \mathrm{L}$ kinetin, and $5 \%(\mathrm{w} / \mathrm{v})$ sucrose for seven weeks. The stock solution of MJ was prepared in ethanol as $50 \mathrm{mM}$ and $\mathrm{MJ}$ were added to the culture as an elicitor as final concentration of $100 \mu \mathrm{M}$, one week before harvest. The adventitious roots were harvested from the culture and washed three times with distilled water to remove the medium on the surface of the adventitious roots. Then, it was immediately frozen with liquid nitrogen and stored in deep-freezer at $-70{ }^{\circ} \mathrm{C}$, and then freeze-dried before further experiments. A voucher specimen (CBNU-WGAR2014) was deposited at the Herbarium of the College of Pharmacy, Chungbuk National University, Korea.

Extraction and isolation of compounds. The dried MJ-treated wild ginseng adventitious root cultures $(5.0 \mathrm{~kg})$ were extracted twice with $25 \mathrm{~L}$ of $80 \% \mathrm{MeOH}$ for $24 \mathrm{~h}$ at room temperature. The methanol extract (1.7 kg) was suspended in $\mathrm{H}_{2} \mathrm{O}$ and partitioned successively with $n$-hexane, $\mathrm{CH}_{2} \mathrm{Cl}_{2}, \mathrm{EtOAc}$ and $n$ - $\mathrm{BuOH}$ to yield corresponding fractions.

The EtOAc fraction (WGE, $21.9 \mathrm{~g}$ ) was subjected to MPLC over silica gel $\left(\mathrm{CH}_{2} \mathrm{Cl}_{2}-\mathrm{MeCN}, 1: 0 \rightarrow 0: 1\right)$ to afford sixteen subfractions (WGE1-WGE16). WGE5 was subjected to MPLC over reverse phase silica gel $\left(\mathrm{MeOH}-\mathrm{H}_{2} \mathrm{O}\right.$, $10: 90 \rightarrow 1: 0)$ to give five subfractions (WGE5A- WGE5E). Compounds $9(17.1 \mathrm{mg}$ ) and 10 (12.6 mg) were purified from WGE5E by semi-preparative HPLC eluting with $\mathrm{MeCN}-\mathrm{H}_{2} \mathrm{O}$ (30:70). WGE9 was subjected to MPLC over reverse phase silica gel $\left(\mathrm{MeOH}-\mathrm{H}_{2} \mathrm{O}, 10: 90 \rightarrow 1: 0\right)$ to give three subfractions (WGE9A- WGE9C). Compound $3\left(29.7 \mathrm{mg}\right.$ ) were purified from WGE9B by semi-preparative HPLC eluting with $\mathrm{MeCN}-\mathrm{H}_{2} \mathrm{O}$ (30:70). WGE15 was subjected to MPLC over reverse phase silica gel $\left(\mathrm{MeOH}-\mathrm{H}_{2} \mathrm{O}, 10: 90 \rightarrow 1: 0\right)$ to give two subfractions (WGE15AWGE15B). Compounds $1(19.9 \mathrm{mg})$ and $5(13.4 \mathrm{mg})$ were purified from WGE15A by semi-preparative HPLC eluting with $\mathrm{MeCN}-\mathrm{H}_{2} \mathrm{O}(30: 70)$.

The $n$ - $\mathrm{BuOH}$ fraction (WGB, $218.3 \mathrm{~g}$ ) was subjected to $\mathrm{HP}-20\left(\mathrm{MeOH}-\mathrm{H}_{2} \mathrm{O}, 0: 1 \rightarrow 1: 0\right)$ to afford five subfractions (WGB1-WGB5). WGB5 was subjected to MPLC over reverse phase silica gel $\left(\mathrm{CH}_{2} \mathrm{Cl}_{2}-\mathrm{MeCN}, 1: 0 \rightarrow 0: 1\right)$ to give nine subfractions (WGE5A- WGE5I). WGB5C was subjected to MPLC over silica gel $\left(\mathrm{MeOH}-\mathrm{H}_{2} \mathrm{O}\right.$, $10: 90 \rightarrow 1: 0)$ to give three subfractions (WGE5C1- WGE5C3). Compounds $8(18.1 \mathrm{mg})$ and $\mathbf{1 1}(11.7 \mathrm{mg})$ were purified from WGE5C1 by semi-preparative HPLC eluting with $\mathrm{MeCN}-\mathrm{H}_{2} \mathrm{O}$ (30:70). Compounds 2 (15.0 mg), $4(15.3 \mathrm{mg}), \mathbf{6}(16.2 \mathrm{mg})$ and $7(16.7 \mathrm{mg})$ were purified from WGE5C2 by semi-preparative HPLC eluting with $\mathrm{MeCN}-\mathrm{H}_{2} \mathrm{O}(40: 60)$.

Jasmogin (5) Light yellow gum; $[\alpha]_{D}^{25}-53.9^{\circ}$ ( c 0.01, MeOH); IR (KBr) $\mathrm{n}_{\max } 3367,1716 \mathrm{~cm}^{-1}$; UV (MeOH) $\lambda_{\max }$ 224, $281 \mathrm{~nm}$; ESIMS $m / z 249[\mathrm{M}+\mathrm{H}]^{+}$; HRESIMS $m / z 251.1254[\mathrm{M}+\mathrm{Na}]^{+}\left(\right.$calcd for $\left.\mathrm{C}_{12} \mathrm{H}_{20} \mathrm{NaO}_{4} 251.1253\right)$; ${ }^{1} \mathrm{H}-\mathrm{NMR}\left(500 \mathrm{MHz}, \mathrm{CD}_{3} \mathrm{OD}\right)$ and ${ }^{13} \mathrm{C}-\mathrm{NMR}\left(225 \mathrm{MHz}, \mathrm{CD}_{3} \mathrm{OD}\right)$, see Table 1.

Jasmoflagin A (6) Light yellow gum; $[\alpha]_{D}^{25}-79.2$ (c 0.05, MeOH); IR (KBr) $\mathrm{n}_{\max } 3537,2915,2337,1725$, $1052 \mathrm{~cm}^{-1}$; UV $(\mathrm{MeOH}) \lambda_{\max } 283,324 \mathrm{~nm}$; ESIMS $m / z 667[\mathrm{M}+\mathrm{Na}]^{+}$; HRESIMS $m / z 667.2354[\mathrm{M}+\mathrm{Na}]^{+}$(calcd for $\mathrm{C}_{33} \mathrm{H}_{40} \mathrm{NaO}_{13}$ 667.2331); ${ }^{1} \mathrm{H}-\mathrm{NMR}\left(500 \mathrm{MHz}, \mathrm{CD}_{3} \mathrm{OD}\right)$ and ${ }^{13} \mathrm{C}-\mathrm{NMR}\left(175 \mathrm{MHz}, \mathrm{CD}_{3} \mathrm{OD}\right)$, see Tables 2 and 3.

Jasmoflagin B (7) Light yellow gum; $[\alpha]_{D}^{25}-97.1$ ( c 0.05, MeOH); IR (KBr) $\mathrm{n}_{\max } 3698,3250,2044,1662,1362$, $802 \mathrm{~cm}^{-1}$; UV $(\mathrm{MeOH}) \lambda_{\max } 212,281,327 \mathrm{~nm}$; ESIMS $m / z 667[\mathrm{M}+\mathrm{Na}]^{+}$; HRESIMS $m / z 667.2354[\mathrm{M}+\mathrm{Na}]^{+}$ (calcd for $\left.\mathrm{C}_{33} \mathrm{H}_{40} \mathrm{NaO}_{13} 667.2361\right)$; ${ }^{1} \mathrm{H}-\mathrm{NMR}\left(700 \mathrm{MHz}, \mathrm{CD}_{3} \mathrm{OD}\right)$ and ${ }^{13} \mathrm{C}-\mathrm{NMR}\left(175 \mathrm{MHz}, \mathrm{CD}_{3} \mathrm{OD}\right)$, see Tables 2 and 3 . 


\begin{tabular}{|l|l|c|}
\hline & $\boldsymbol{\delta}_{\mathrm{H}}$ & $\boldsymbol{\delta}_{\mathrm{C}}$ \\
\hline 1 & & 175.9 \\
\hline 2 & $2.55(\mathrm{dd}, 14.4,3.6), 2.15(\mathrm{~m})$ & 39.1 \\
\hline 3 & $2.16(\mathrm{~m})$ & 38.5 \\
\hline 4 & $1.88(\mathrm{~m}), 1.64(\mathrm{~m})$ & 32.8 \\
\hline 5 & $2.11(\mathrm{~m}), 1.33(\mathrm{~m})$ & 28.8 \\
\hline 6 & $4.15(\mathrm{~m})$ & 73.4 \\
\hline 7 & $1.46(\mathrm{~m})$ & 50.9 \\
\hline 8 & $2.29(\mathrm{~m}), 2.24(\mathrm{~m})$ & 25.5 \\
\hline 9 & $5.52(\mathrm{~m})$ & 128.8 \\
\hline 10 & $5.42(\mathrm{dd}, 10.4,8.8)$ & 134.0 \\
\hline 11 & $4.68(\mathrm{dq}, 8.8,6.4)$ & 63.2 \\
\hline 12 & $1.23(\mathrm{~d}, 6.4)$ & 22.5 \\
\hline
\end{tabular}

Table 1. NMR spectroscopic data for compound $\mathbf{5}\left(\mathrm{CD}_{3} \mathrm{OD}\right)$.

\begin{tabular}{|c|c|c|c|c|c|c|}
\hline No & 6 & 7 & 8 & 9 & 10 & 11 \\
\hline 2 & 5.40, dd $(13.0,3.0)$ & $5.41, \mathrm{dd}(12.5,3.5)$ & $5.41, \mathrm{dd}(12.6,3.5)$ & $5.38, \mathrm{dd}(13.0,2.8)$ & $5.42, \mathrm{dd}(13.0,3.0)$ & 5.42, dd $(12.7,2.9)$ \\
\hline \multirow{2}{*}{3} & $3.17, \mathrm{dd}(17.0,13.0)$ & $3.17, \mathrm{dd}(17.0,12.5)$ & $3.18, \mathrm{dd}(17.5,12.6)$ & 3.14, dd $(17.1,13.0)$ & 3.16, dd $(17.0,13.0)$ & 3.18, dd $(17.1,12.7)$ \\
\hline & $2.77, \mathrm{dd}(17.0,3.0)$ & $2.77, \mathrm{dd}(17.0,3.5)$ & 2.76 , dd $(17.5,3.5)$ & $2.75, \mathrm{dd}(17.1,2.8)$ & $2.76, \mathrm{dd}(17.0,3.0)$ & $2.78, \mathrm{dd}(17.1,2.9)$ \\
\hline 6 & $6.20, \mathrm{~d}(2.1)$ & $6.20, \mathrm{~d}(2.2)$ & $6.20, \mathrm{~d}(2.2)$ & $6.20, \mathrm{~d}(2.3)$ & $6.21, \mathrm{~d}(2.1)$ & $6.21, \mathrm{~d}(2.1)$ \\
\hline 8 & $6.23, \mathrm{~d}(2.1)$ & $6.23, \mathrm{~d}(2.2)$ & $6.25 \mathrm{~d}(2.2)$ & $6.23, \mathrm{~d}(2.3)$ & $6.24, \mathrm{~d}(2.1)$ & $6.24, \mathrm{~d}(2.1)$ \\
\hline $2^{\prime} / 6^{\prime}$ & $7.34, \mathrm{~d}(8.0)$ & $7.34, \mathrm{~d}(8.5)$ & $7.34, \mathrm{~d}(8.5)$ & $7.33, \mathrm{~d}(8.5)$ & $7.35, \mathrm{~d}(8.3)$ & $7.35, \mathrm{~d}(8.6)$ \\
\hline $3^{\prime} / 5^{\prime}$ & $6.84, \mathrm{~d}(8.0)$ & 6.84, d (8.5) & 6.83, d (8.5) & 6.84, d (8.5) & 6.85, d (8.3) & 6.85, d (8.6) \\
\hline $1^{\prime \prime}$ & $4.96, \mathrm{~d}(7.4)$ & $4.96, \mathrm{~d}(7.4)$ & $4.97, \mathrm{~d}(7.5)$ & $4.95, \mathrm{~d}(7.5)$ & 4.97, d (7.4) & $4.96, \mathrm{~d}(7.5)$ \\
\hline $2^{\prime \prime}$ & $3.48 \mathrm{~m}$ & $3.48 \mathrm{~m}$ & $3.50 \mathrm{~m}$ & $3.47 \mathrm{~m}$ & $3.49 \mathrm{~m}$ & $3.48 \mathrm{~m}$ \\
\hline $3^{\prime \prime}$ & $3.46 \mathrm{~m}$ & $3.47 \mathrm{~m}$ & $3.47 \mathrm{~m}$ & $3.46 \mathrm{~m}$ & $3.47 \mathrm{~m}$ & $3.46 \mathrm{~m}$ \\
\hline $4^{\prime \prime}$ & $3.34 \mathrm{~m}$ & $3.34 \mathrm{~m}$ & $3.33 \mathrm{~m}$ & $3.34 \mathrm{~m}$ & $3.34 \mathrm{~m}$ & $3.33 \mathrm{~m}$ \\
\hline $5^{\prime \prime}$ & $3.70 \mathrm{~m}$ & $3.71 \mathrm{~m}$ & $3.71 \mathrm{~m}$ & $3.69 \mathrm{~m}$ & $3.72, \mathrm{t}(9.8)$ & $3.72 \mathrm{~m}$ \\
\hline \multirow{2}{*}{$6 "$} & 4.43, dd (11.7. 2.1) & $4.43, \mathrm{dd}(11.9,2.1)$ & 4.51, dd $(11.8,2.1)$ & $4.42, \mathrm{dd}(11.8,1.9)$ & $4.48 \mathrm{dd}(11.8,2.1)$ & $4.47 \mathrm{dd}(11.8,1.9)$ \\
\hline & $4.21 \mathrm{~m}$ & $4.22 \mathrm{~m}$ & $4.18 \mathrm{~m}$ & $4.21 \mathrm{~m}$ & $4.15 \mathrm{~m}$ & $4.15 \mathrm{~m}$ \\
\hline \multirow{2}{*}{$2^{\prime \prime \prime}$} & $2.52 \mathrm{~m}$ & $2.54 \mathrm{~m}$ & $2.67 \mathrm{~m}$ & $2.54 \mathrm{~m}$ & $2.33, \mathrm{~m}$ & $2.35 \mathrm{~m}$ \\
\hline & $2.22 \mathrm{~m}$ & $2.20 \mathrm{~m}$ & $2.36 \mathrm{~m}$ & $2.18 \mathrm{~m}$ & $2.31, \mathrm{~m}$ & $2.30 \mathrm{~m}$ \\
\hline $3^{\prime \prime \prime}$ & $2.08 \mathrm{~m}$ & $2.08 \mathrm{~m}$ & $2.19 \mathrm{~m}$ & $2.06 \mathrm{~m}$ & $1.96 \mathrm{~m}$ & $1.96 \mathrm{~m}$ \\
\hline \multirow{2}{*}{$4^{\prime \prime \prime}$} & $1.99 \mathrm{~m}$ & $1.74 \mathrm{~m}$ & $1.38 \mathrm{~m}$ & $1.96 \mathrm{~m}$ & $1.81 \mathrm{~m}$ & $1.85 \mathrm{~m}$ \\
\hline & $1.19 \mathrm{~m}$ & $1.53 \mathrm{~m}$ & $2.10 \mathrm{~m}$ & $1.20 \mathrm{~m}$ & $0.99 \mathrm{~m}$ & $1.52 \mathrm{~m}$ \\
\hline \multirow{2}{*}{$5^{\prime \prime \prime}$} & $1.75 \mathrm{~m}$ & $1.98 \mathrm{~m}$ & $2.30 \mathrm{~m}$ & $1.73 \mathrm{~m}$ & $1.87 \mathrm{~m}$ & $1.83 \mathrm{~m}$ \\
\hline & $1.54 \mathrm{~m}$ & $1.18 \mathrm{~m}$ & $2.31 \mathrm{~m}$ & $1.55 \mathrm{~m}$ & $1.47 \mathrm{~m}$ & $1.12 \mathrm{~m}$ \\
\hline $6^{\prime \prime \prime}$ & $4.05 \mathrm{~m}$ & $4.07 \mathrm{~m}$ & - & $4.07 \mathrm{~m}$ & $4.48 \mathrm{~m}$ & $4.48 \mathrm{~m}$ \\
\hline $7^{\prime \prime \prime}$ & $1.24 \mathrm{~m}$ & $1.24 \mathrm{~m}$ & $1.71 \mathrm{~m}$ & $1.23 \mathrm{~m}$ & $2.14 \mathrm{~m}$ & $2.13 \mathrm{~m}$ \\
\hline \multirow{2}{*}{$8^{\prime \prime \prime}$} & $2.31 \mathrm{~m}$ & $2.20 \mathrm{~m}$ & $2.03 \mathrm{~m}$ & $2.12 \mathrm{~m}$ & $1.70 \mathrm{~m}$ & $1.70 \mathrm{~m}$ \\
\hline & $2.04 \mathrm{~m}$ & $2.09 \mathrm{~m}$ & $2.23 \mathrm{~m}$ & $2.12 \mathrm{~m}$ & $1.60 \mathrm{~m}$ & $1.62 \mathrm{~m}$ \\
\hline $9^{\prime \prime \prime}$ & $5.43 \mathrm{~m}$ & $5.51 \mathrm{~m}$ & $5.26 \mathrm{~m}$ & $5.37 \mathrm{~m}$ & $4.15 \mathrm{~m}$ & $3.69 \mathrm{~m}$ \\
\hline $10^{\prime \prime \prime}$ & $5.41 \mathrm{~m}$ & $5.41 \mathrm{~m}$ & $5.40 \mathrm{~m}$ & $5.36 \mathrm{~m}$ & $5.37 \mathrm{~m}$ & $3.24 \mathrm{~m}$ \\
\hline $11^{\prime \prime \prime}$ & $4.62 \mathrm{~m}$ & $2.37 \mathrm{~m}, 2.25 \mathrm{~m}$ & $4.58 \mathrm{~m}$ & $2.06 \mathrm{~m}$ & $5.65 \mathrm{~m}$ & $1.40 \mathrm{~m}$ \\
\hline $12^{\prime \prime \prime}$ & $1.20, \mathrm{~d}(6.4)$ & $3.56 \mathrm{~m}$ & $1.18, \mathrm{~d}(6.3)$ & $0.96, \mathrm{t}(7.5)$ & $1.68, \mathrm{~d}(6.3)$ & $0.97, \mathrm{dd}(14.1,7.1)$ \\
\hline
\end{tabular}

Table 2. ${ }^{1} \mathrm{H}$ NMR spectroscopic data for compounds 6-11 $\left(\mathrm{CD}_{3} \mathrm{OD}\right)$.

Jasmoflagin C (8) Light yellow gum; $[\alpha]_{D}^{25}$-34.2 (c 0.01, MeOH); IR (KBr) $\mathrm{n}_{\max } 3861,3563,2360,1515$, $1176 \mathrm{~cm}^{-1}$; UV $(\mathrm{MeOH}) \lambda_{\max } 215,283,327 \mathrm{~nm}$; ESIMS m/z $667[\mathrm{M}+\mathrm{Na}]^{+}$; HRESIMS $m / z 667.2360[\mathrm{M}+\mathrm{Na}]^{+}$ (calcd for $\left.\mathrm{C}_{33} \mathrm{H}_{40} \mathrm{NaO}_{13} 667.2361\right)$; ${ }^{1} \mathrm{H}-\mathrm{NMR}\left(700 \mathrm{MHz}, \mathrm{CD}_{3} \mathrm{OD}\right)$ and ${ }^{13} \mathrm{C}-\mathrm{NMR}\left(175 \mathrm{MHz}, \mathrm{CD}_{3} \mathrm{OD}\right)$, see Tables 2 and 3.

Jasmoflagin D (9) Light yellow gum; $[\alpha]_{D}^{25}-38.5(c 0.05, \mathrm{MeOH}) ; \mathrm{IR}(\mathrm{KBr}) \mathrm{n}_{\max } 3876,3617,2869,1639$, $887 \mathrm{~cm}^{-1}$; UV $(\mathrm{MeOH}) \lambda_{\max } 212,281,389 \mathrm{~nm}$; ESIMS $m / z 667[\mathrm{M}+\mathrm{Na}]^{+} ;$HRESIMS $m / z 651.2404[\mathrm{M}+\mathrm{Na}]^{+}$ (calcd for $\left.\mathrm{C}_{33} \mathrm{H}_{40} \mathrm{NaO}_{12} 651.2412\right)$; ${ }^{1} \mathrm{H}-\mathrm{NMR}\left(50 \mathrm{MHz}, \mathrm{CD}_{3} \mathrm{OD}\right)$ and ${ }^{13} \mathrm{C}-\mathrm{NMR}\left(100 \mathrm{MHz}, \mathrm{CD}_{3} \mathrm{OD}\right)$, see Tables 2 and 3 . 


\begin{tabular}{|l|r|r|r|r|l|r|}
\hline & $\mathbf{6}$ & \multicolumn{1}{|l}{7} & $\mathbf{8}$ & $\mathbf{9}$ & $\mathbf{1 0}$ & $\mathbf{1 1}$ \\
\hline 2 & 79.3 & 79.3 & 79.4 & 79.3 & 79.4 & 79.4 \\
\hline 3 & 43.1 & 43.1 & 43.1 & 43.0 & 43.1 & 43.1 \\
\hline 4 & 197.1 & 197.1 & 197.2 & 197.1 & 197.2 & 197.2 \\
\hline 5 & 163.2 & 163.2 & 163.2 & 163.2 & 163.3 & 163.3 \\
\hline 6 & 96.7 & 96.7 & 96.8 & 96.7 & 96.7 & 96.7 \\
\hline 7 & 165.5 & 165.5 & 165.4 & 165.5 & 165.5 & 165.4 \\
\hline 8 & 95.7 & 95.7 & 95.7 & 95.7 & 95.6 & 95.6 \\
\hline 9 & 163.5 & 163.5 & 163.4 & 163.5 & 163.5 & 163.5 \\
\hline 10 & 103.6 & 103.6 & 103.6 & 103.6 & 103.6 & 103.6 \\
\hline $1^{\prime}$ & 129.5 & 129.5 & 129.5 & 129.5 & 129.5 & 129.6 \\
\hline $2^{\prime} / 6^{\prime}$ & 127.6 & 127.5 & 127.6 & 127.6 & 127.6 & 127.8 \\
\hline $3^{\prime} 5^{\prime}$ & 115.0 & 115.0 & 115.1 & 115.0 & 115.0 & 115.0 \\
\hline $4^{\prime}$ & 157.7 & 157.7 & 157.8 & 157.7 & 157.8 & 157.7 \\
\hline $1^{\prime \prime}$ & 99.8 & 99.8 & 99.8 & 99.8 & 99.8 & 99.9 \\
\hline $2^{\prime \prime}$ & 76.4 & 76.4 & 76.3 & 76.4 & 76.3 & 76.3 \\
\hline $3^{\prime \prime}$ & 73.2 & 73.2 & 73.2 & 73.2 & 73.2 & 73.2 \\
\hline $4^{\prime \prime}$ & 70.3 & 70.3 & 70.3 & 70.3 & 70.4 & 70.4 \\
\hline $5^{\prime \prime}$ & 74.2 & 74.2 & 74.2 & 74.2 & 74.2 & 74.2 \\
\hline $6^{\prime \prime}$ & 63.2 & 63.2 & 63.5 & 63.2 & 63.5 & 63.5 \\
\hline $1^{\prime \prime \prime}$ & 173.4 & 173.5 & 172.3 & 173.5 & 173 & 173.0 \\
\hline $2^{\prime \prime \prime}$ & 38.4 & 38.7 & 38.2 & 43.0 & 38.9 & 39.0 \\
\hline $3^{\prime \prime \prime}$ & 38.2 & 38.4 & 37.7 & 38.4 & 41.9 & 42.0 \\
\hline $4^{\prime \prime \prime}$ & 28.8 & 32.5 & 26.6 & 28.7 & 31.5 & 32.2 \\
\hline $5^{\prime \prime \prime}$ & 32.3 & 28.7 & 25.0 & 32.7 & 32.4 & 31.4 \\
\hline $6^{\prime \prime \prime}$ & 73.2 & 73.4 & 220.1 & 73.6 & 84.5 & 84.8 \\
\hline $7^{\prime \prime \prime}$ & 50.7 & 50.7 & 53.5 & 50.8 & 49.5 & 49.5 \\
\hline $8^{\prime \prime \prime}$ & 25.7 & 25.4 & 37.0 & 25.2 & 38.2 & 33.7 \\
\hline $9^{\prime \prime \prime}$ & 130.1 & 130.4 & 126.2 & 127.8 & 79.1 & 81.5 \\
\hline $10^{\prime \prime \prime}$ & 133.8 & 126.0 & 135.6 & 131.6 & 130.8 & 74.5 \\
\hline $11^{\prime \prime \prime}$ & 62.5 & 30.3 & 62.8 & 20.1 & 127.7 & 26.2 \\
\hline $12^{\prime \prime \prime}$ & 22.2 & 61.2 & 22.4 & 13.3 & 16.5 & 9.2 \\
\hline & & & & & & \\
\hline
\end{tabular}

Table 3. ${ }^{13} \mathrm{C}$ NMR spectroscopic data for compounds 6-11 $\left(\mathrm{CD}_{3} \mathrm{OD}\right)$.

Jasmoflagin E (10) Light yellow gum; $[\alpha]_{D}^{25}-92.2$ ( c 0.05, MeOH); IR (KBr) $\mathrm{n}_{\max } 3751,3311,2331,1662$, $824 \mathrm{~cm}^{-1}$; UV $(\mathrm{MeOH}) \lambda_{\max } 283,325 \mathrm{~nm}$; ESIMS $m / z 667[\mathrm{M}+\mathrm{Na}]^{+}$; HRESIMS $m / z 651.2334[\mathrm{M}+\mathrm{Li}]^{+}(\mathrm{calcd}$ for $\left.\mathrm{C}_{33} \mathrm{H}_{40} \mathrm{LiO}_{13} 651.2624\right) ;{ }^{1} \mathrm{H}-\mathrm{NMR}\left(400 \mathrm{MHz}, \mathrm{CD}_{3} \mathrm{OD}\right)$ and ${ }^{13} \mathrm{C}-\mathrm{NMR}\left(100 \mathrm{MHz}, \mathrm{CD}_{3} \mathrm{OD}\right)$, see Tables 2 and 3.

Jasmoflagin F (11) Light yellow gum; $[\alpha]_{D}^{25}-64.8(c 0.05, \mathrm{MeOH}) ; \mathrm{IR}(\mathrm{KBr}) \mathrm{n}_{\max } 3706,3494,2969,1577,1058$, $833 \mathrm{~cm}^{-1}$; UV (MeOH) $\lambda_{\max } 211,283,325 \mathrm{~nm}$; ESIMS m/z $662[\mathrm{M}+\mathrm{H}]^{+}$; HRESIMS m/z 668.2415 [M+ Li] $]^{+}$(calcd for $\mathrm{C}_{33} \mathrm{H}_{43} \mathrm{NLiO}_{13}$ 668.2889); ${ }^{1} \mathrm{H}-\mathrm{NMR}\left(700 \mathrm{MHz}, \mathrm{CD}_{3} \mathrm{OD}\right)$ and ${ }^{13} \mathrm{C}-\mathrm{NMR}\left(175 \mathrm{MHz}, \mathrm{CD}_{3} \mathrm{OD}\right)$, see Tables 2 and 3.

Measurement of LPS-induced NO production. Inhibitory effect of compounds on lipopolysaccharide (LPS)-induced nitric oxide (NO) production was assessed using RAW264.7 macrophage cell lines. RAW 264.7 cells were treated with $1 \mu \mathrm{g} / \mathrm{ml}$ LPS in the presence or absence of compounds. After $24 \mathrm{~h}$ incubation, the cell medium was mixed with Griess reagent and the amount of NO formed was determined by measuring the absorbance at $550 \mathrm{~nm}$ in an ELISA reader. Cell viability of the remaining cells was determined by MTT assay.

Received: 13 February 2021; Accepted: 25 May 2021

Published online: 09 June 2021

\section{References}

1. Ochoa-Villarreal, M. et al. Plant cell culture strategies for the production of natural products. BMB Rep. 49, 149-158 (2016).

2. Nosov, A. M. Application of cell technologies for production of plant-derived bioactive substances of plant origin. Appl. Biochem. Microbiol. 48, 609-624 (2012).

3. Rahimi, S., Kim, Y. J. \& Yang, D. C. Production of ginseng saponins: elicitation strategy and signal transductions. Appl. Biochem. Microbiol. 99, 6987-6996 (2015).

4. Goel, M. K., Mehrotra, S. \& Kukreja, A. K. Elicitor-induced cellular and molecular events are responsible for productivity enhancement in hairy root cultures: an insight study. Appl. Biochem. Biotechnol. 165, 1342-1355 (2011). 
5. Farkya, S., Bisaria, V. S. \& Srivastava, A. K. Biotechnological aspects of the production of the anticancer drug podophyllotoxin. Appl. Biochem. Biotechnol. 65, 504-519 (2004).

6. Ferreira, S. V. \& Sant'Anna, C. Impact of culture conditions on the chlorophyll content of microalgae for biotechnological applications. World J. Microbiol. Biotechnol. 33, 20 (2017).

7. Ramirez-Estrada, K. et al. Elicitation, an effective strategy for the biotechnological production of bioactive high-added value compounds in plant cell factories. Molecules 21, 182 (2016).

8. Portu, J., López, R., Santamaría, P. \& Garde-Cerdán, T. Elicitation with methyl jasmonate supported by precursor feeding with phenylalanine: effect on Garnacha grape phenolic content. Food Chem. 237, 416-422 (2017).

9. Binns, S. E., Inparajah, I., Baum, B. R. \& Arnason, J. T. Methyl jasmonate increases reported alkamides and ketoalkene/ynes in Echinacea pallida (Asteraceae). Phytochemistry 57, 417-420 (2001).

10. Fraga, B. M. et al. Bioactive constituents from transformed root cultures of Nepeta teydea. Phytochemistry 133, 59-68 (2017).

11. Magallanes-Noguera, C. et al. Plant tissue cultures as sources of new ene- and ketoreductase activities. J. Biotechnol. 251, 14-20 (2017).

12. Patel, S. \& Rauf, A. Adaptogenic herb ginseng (Panax) as medical food: Status quo and future prospects. Biomed. Pharmacother. 85, 120-127 (2017).

13. Ru, W. et al. Chemical constituents and bioactivities of Panax ginseng (C. A. Mey.). Drug Discov. Ther. 9, 23-32 (2015).

14. Wang, T. et al. Traditional uses, botany, phytochemistry, pharmacology and toxicology of Panax notoginseng (Burk.) F.H. Chen: a review. J. Ethnopharmacol. 188, 234-258 (2016).

15. Park, J. G., Son, Y. J., Aravinthan, A., Kim, J. H. \& Cho, J. Y. Korean red ginseng water extract arrests growth of xenografted lymphoma cells. J. Ginseng Res. 40, 431-436 (2016).

16. Wang, W. et al. Sesquiterpenoids from the root of Panax ginseng attenuates lipopolysaccharide-induced depressive-like behavior through the brain-derived neurotrophic factor/tropomyosin-related kinase B and sirtuin type 1 /nuclear factor- $\mathrm{kB}$ signaling pathways. J. Agric. Food Chem. 66, 265-271 (2018).

17. Pan, H. Y., Qu, Y., Zhang, J. K., Kang, T. G. \& Dou, D. Q. Antioxidant activity of ginseng cultivated under mountainous forest with different growing years. J. Ginseng Res. 37, 355-360 (2013).

18. Sun, H. et al. Proteomic analysis of amino acid metabolism differences between wild and cultivated Panax ginseng. J. Ginseng Res. 40, 113-120 (2016).

19. Murphy, H. N., Kim, Y. S., Park, S. Y. \& Paek, K. Y. Biotechnological production of caffeic acid derivatives from cell and organ cultures of Echinacea species. Appl. Biocrobiol. Biotechnol. 98, 7707-7717 (2014).

20. Yu, K. W., Gao, W. Y., Son, S. H. \& Paek, K. Y. Improvement of ginsenoside production by jasmonic acid and some other elicitors in hairy root culture of ginseng (Panax ginseng C. A. Meyer). In Vitro Cell Dev. Biol. Plant 36, 424-428 (2000).

21. Liu, Q. et al. Optimization of extraction condition of methyl jasmonate-treated wild ginseng adventitious root cultures using response surface methodology. Nat. Prod. Sci. 17, 93-98 (2018).

22. Jeon, S. H., Chun, W. J., Choi, Y. J. \& Kwon, Y. S. Cytotoxic constituents from the bark of Salix hulteni. Arch. Pharm. Res. 31, 978-982 (2008).

23. Ma, X. L. et al. Nitric oxide inhibitory flavonoids from traditional Chinese medicine formula Baoyuan decoction. Fitoterapia 103, 252-259 (2015).

24. Rayan, S., Fossen, T., Nateland, H. S. \& Andersen, O. M. Isolation and identification of flavonoids, including flavone rotamers, from the herbal drug "Crataegi folium cum flore" (hawthorn). Phytochem. Anal. 16, 334-341 (2005).

25. Seto, H. et al. Easy preparation of methyl 7-epi-jasmonate and four stereoisomers of methyl cucurbate, and assessment of the stereogenic effect of jasmonate on phytohormonal activities. Biosci. Biotechnol. Biochem. 63, 361-367 (1999).

\section{Acknowledgements}

This work was supported by Korea Institute of Planning and Evaluation for Technology in Food, Agriculture, Forestry and Fisheries (IPET) through Advanced Production Technology Development Program, funded by Ministry of Agriculture, Food and Rural Affairs (grant number 315013-4) and Medical Research Center program (2017R1A5A2015541) through the National Research Foundation of Korea.

\section{Author contributions}

Q.L. and M.K.L. designed and coordinated the project. Q.L., S.B.K., Y.H.J, J.H.A. and A.T. performed the extraction, isolation and structural identification of the compounds. D.E.K., B.Y.C. and S.Y.K. carried out the biological assays. C.-S.J. and S.Y.P. performed the mountain ginseng root cultures. Q.L., S.Y.P., B.Y.H. and M.K.L. analyzed the data. Q.L. and M.K.L. wrote the manuscript and all authors reviewed the manuscript.

\section{Competing interests}

The authors declare no competing interests.

\section{Additional information}

Supplementary Information The online version contains supplementary material available at https://doi.org/ 10.1038/s41598-021-91850-8.

Correspondence and requests for materials should be addressed to S.-Y.P. or M.K.L.

Reprints and permissions information is available at www.nature.com/reprints.

Publisher's note Springer Nature remains neutral with regard to jurisdictional claims in published maps and institutional affiliations. 
(c) (i) Open Access This article is licensed under a Creative Commons Attribution 4.0 International cc) License, which permits use, sharing, adaptation, distribution and reproduction in any medium or format, as long as you give appropriate credit to the original author(s) and the source, provide a link to the Creative Commons licence, and indicate if changes were made. The images or other third party material in this article are included in the article's Creative Commons licence, unless indicated otherwise in a credit line to the material. If material is not included in the article's Creative Commons licence and your intended use is not permitted by statutory regulation or exceeds the permitted use, you will need to obtain permission directly from the copyright holder. To view a copy of this licence, visit http://creativecommons.org/licenses/by/4.0/.

(C) The Author(s) 2021 